\title{
Cloud Payroll System as the Model of the Fourth Industry Revolution (Industry 4.0)
}

\section{Heri Yuliyanto}

Accounting Study Program, Vocational Program of Universitas Indonesia, Kota Depok, Jawa Barat 16424, Indonesia

\section{Abstract}

Today, we stand on the cusp of a fourth industrial revolution (Industry 4.0 era). The domestic industries have to prepare for the revolution. Online base system or the Internet has to integrate an online-based system in a manufacturing process, that is, Claud Payroll System (CPS). The CPS is a suitable business model in the Industry 4.0 era. It involves three companies, namely PT CR, CP Management and KAP ADC. They can focus on their core business and expand into the global market. On the other hand, Internal control can be applied so that it can reduce the occurrence of fraud.

Corresponding Author: Heri Yuliyanto heri.aqwam@gmail.com

Received: 8 June 2018

Accepted: 17 July 2018

Published: 8 August 2018

Publishing services provided by Knowledge E

(c) Heri Yuliyanto. This article is distributed under the terms of the Creative Commons

Attribution License, which permits unrestricted use and redistribution provided that the original author and source are credited.

Selection and Peer-review under the responsibility of the 2 nd ICVHE Conference Committee.

\section{G OPEN ACCESS}

Keywords: claud base system, payroll, Industry 4.0, internal control

\section{Introduction}

Today we stand on the cusp of a fourth industrial revolution (Industry 4.0 era) that characterized by the increasing digitization and interconnection of products, value chains and business models. In the Industry 4.0 era, Information and Communication Technology (ICT) have been important component to manage industry, and its covers three aspects: (1) digitization and increased integration of vertical and horizontal value chain, (2) digitization of product and service offerings, and (3) introduction of innovative digital business models [1].

Industry Minister of Indonesia, Airlangga Hartanto, remind the industry players in the country to prepare for the Industry 4.0 era. The industry players have to change the manufacturing process by integrating an online-based system in a production chain [2]. This is consistent with results from studies in Europe, companies in the Blue Continent invest up to 140 billion euros until 2020 for the use of Internet applications in the industry [1].

On of industrial process business interesting to explore the related to fourth industrial revolution is payroll system. Payroll policies and procedure are critical to protecting 
the payroll expenditures that constitute a major expense for most organization. The accuracy and timelines of correct payroll administration is crucial to the success of every organization, large or small [3]. It is a function that constantly is under deadline, and employee s do not empathize with organization that don't pay them accurately an on time [4].

In general, a company's payroll system is managed by the human resources department of the company. However, in certain circumstances there are companies that outsourced their payroll system to other companies who are more expert in handling payroll system. We are familiar with the term outsourcing. Thus the company more able to focus on developing its core business.

Couse of the payroll business process is critical, so internal controls and monitoring are needed if your company outsources payroll to a third party, especially to ensure that payroll taxes are paid on timely basis and in full, so you can void penalties and double payments [5]. Internal controls in the company is also supported by the payroll and wage accounting system. With the good internal control system payroll accounting and remuneration, procedures for payment of salaries and wages of employees will go smoothly meet the applicable provisions [6].

\section{Problem Statemant}

As described in previous sections (Introduction) that said national industries have to prepare to implement Industry 4.0. In other hand, many employers are aware that payroll administration is very complex and tedious [8]; therefore, it has become one of the most commonly outsourced functions nowadays. So, it is interesting to learn; (1) whether outsourcing payroll system can be said to be a form of preparation for Industry 4.0 era, and (2) what factors must be considered specially in internal control aspects, in order to successfully outsource the implementation of the payroll system and provide benefits to the enterprise.

For exploring the topics, the article use case study about three-party payroll system of PT ABC, which includes PT ABC, PT XYZ and KAP AAA. It is a case study of Ayunda Clarasari's internship report that entitled "Analysis of Internal Control System Payroll: Case Study Three Parties Payroll System of PT CR."

\section{The 4th Industrial Revolution (Industry 4.0)}




\subsection{Drivers, barriers and initiatives of Industry 4.0}

We are currently experiencing the fourth Industrial Revolution in terms of cyber physical systems. These systems are industrial automation systems that enable many innovative functionalities through their networking and their access to the cyber world, thus changing our everyday lives significantly. In this context, new business models, work processes and development methods that are currently unimaginable will arise. These changes will also strongly influence the society and people. Family life, globalization, markets, etc., will have to be redefined. However, the Industry 4.0 simultaneously shows characteristics that represent the challenges regarding the development of cyber-physical systems, reliability, security and data protection. Following a brief introduction to Industry 4.0, this article presents a prototypical application that demonstrates the essential aspects [9].

Following the first Industrial Revolution 'Mechanization' as a result of the invention of the steam engine, the second 'Mass production' with the help of electricity and the third 'Digitization' by the use of Electronics and IT, this marks the dawn of the fourth Industrial Revolution through the use of cyber physical systems (CPS) and the Internet of Things and Services. In the field CPS, Germany has a leading role and can draw on almost 20 years of experience. The integration of cyber technologies that make the products Internet-enabled facilitates innovative services to achieve, among other things, Internet-based diagnostics, maintenance, operation, etc., in a cost-effective and efficient manner. Moreover, it helps realization of new business models, operating concepts and smart controls, and focusing on the user and his or her individual needs. The goal of the Industry 4.0 is the emergence of digital factories that are to be characterized by the following features [10]:

- Smart networking, Automated systems and equipment, internal logistics systems and operating supplies are consistently intermeshed with help of cyber technology, such as wireless and wireline communication services, smart actuators and sensors and telecommunication technologies

- Mobility, Mobile devices such as smartphones and tablets have already made inroads in industrial automation

- Flexibility, Industry 4.0 allows a high flexibility both in the development, diagnostics and maintenance as well as in the operation of automated systems 
- Integration of customers, With Industry 4.0 it will be possible to customize the products to the specific and individual needs of customers. Automated systems of the 21st Century adapt to the needs and abilities of users of all age groups

- New innovative business models, Production in the future will be distributed and flexible. New development processes, infrastructure and services will arise. The products will become modular and configurable so that the product can be adapted to the specific requirements.

In other hand, Ronald Resendahl at.al say that One key element of this initiative is the 'Industry 4.0 component', a self-aware and self-adaptable production system component. [12]. The German initiative Industry 4.0 will involve amongst other issues networking and integration of several different parties (e.g., manufacturing companies, suppliers, customers, sub-contractors) through value networks. This initiative underpins that this collaborative partnership will only be feasible if standardization and open standards are available. For this purpose a reference architecture is needed to provide a technical description of these standards. In this context interoperability plays a major role for the seamless exchange of data and information among partners in these value networks. Interoperability involves the interaction of different systems and their users. Information modeling is a key concept for providing interoperability. In this article, we present a standards framework that highlights how existing standards intertwine to establish value networks in an Industry 4.0 context [11].

Industry 4.0 (the fourth industrial revolution) encapsulates future industry development trends to achieve more intelligent manufacturing processes, including reliance on Cyber- Physical Systems (CPS), construction of Cyber-Physical Production Systems (CPPS), and implementation and operation of smart factories. This article introduces relevant aspects of Industry 4.0 in relation to strategic planning, key technologies, opportunities, and challenges. Strategic planning includes construction of a CPS network, discussion of two major themes which are based on the smart factory and intelligent production, achieving three integrations (horizontal integration, vertical integration and end-to-end integration) and achieving eight plans which consist of the formulation of system standardization, efficient management etc. Finally, it referred to the enlightenment for China's manufacturing industries, to build China's Industry 4.0. [13].

The term Industry 4.0 collectively refers to a wide range of current concepts, whose clear classification concerning a discipline as well as their precise distinction is not possible in individual cases. In the following fundamental concepts are listed [14]: 


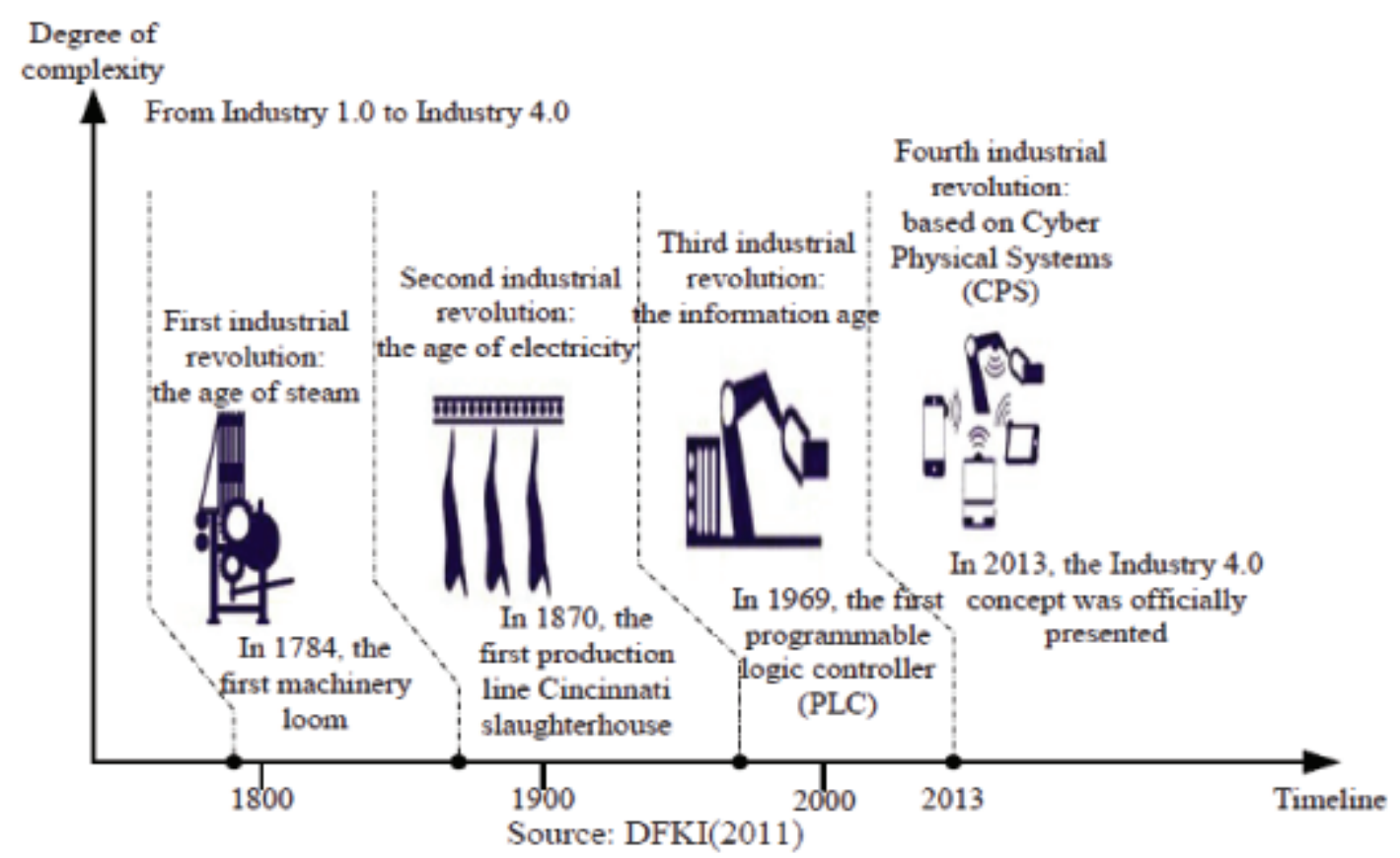

Figure 1: The four stages of the industrial revolution.

- Smart Factory: Manufacturing will completely be equipped with sensors, actors, and autonomous systems

- Cyber-physical Systems: The physical and the digital level merge. If this covers the level of production as well as that of the products, systems emerge whose physical and digital representation cannot be differentiated in a reasonable way anymore.

- Self-organization: Existing manufacturing systems are becoming increasingly decentralized. This comes along with a decomposition of classic production hierarchy and a change toward decentralized self-organization

- New systems in distribution and procurement: Distribution and procurement will increasingly be individualized. Connected processes will be handled by using various different channels.

- New systems in the development of products and services: Product and service development will be individualized. In this context, approaches of open innovation and product intelligence as well as product memory are of outstanding importance.

- Adaptation to human needs: New manufacturing systems should be designed to follow human needs instead of the reverse. 
- Corporate Social Responsibility: Sustainability and resource-efficiency are increasingly in the focus of the design of industrial manufacturing processes. These factors are fundamental framework conditions for succeeding products.

\section{Internal Control of Payroll System}

\subsection{Internal control framework}

Committee of Sponsoring Organization of the Treadway Commission (COSO) define the Internal control as a process, effected by an entity's board of directors, management and the other personnel, design to provide reasonable assurance regarding the achievement of the objective in the following categories:

- effectiveness and efficiency of operations

- reliability of financial reporting

- compliance with applicable law and regulations.

The objectives of internal control consists of five components, that is, (1) control environment, (2) risk assessment, (3) control activities, (4) information and communication, and (5) monitoring [15]. Criteria of Control Board (CoCo) define control as "those elements of organization (including its resources, systems, process, culture, structure and tasks) that, taken together support people in the achievement of the organization's objectives that include three categories of objectives.' That are (1) effectiveness and efficiency of operations, (2) reliability of internal and external reporting, and (2) compliance with applicable law and regulations and internal policies. The last definition, Control Objectives for Information and Related Technology (COBIT) defines control as "the polices, procedure, practices and organization structures designed to provide reasonable assurance that business objectives will be achieved and that undesired events will be prevented or detected and corrected" [15]. We can conclude that the board of directors, manager and officers within organization have to responsible for ensuring that effectives control and risk management system are in place.

\subsection{Payroll system}

Payroll is a painstakingly detail process with no margin for error that constantly under deadline, and employees do not empathize with organization that don't pay them accurately and on time [16]. Some company manage their payroll system by their 
department, but for circumstance company can outsource their payroll system to third party. Flexibility, integration, control pay and security lower cost are reasons to run your own payroll. The other hand, some reasons can be considered to outsource their payroll. It's are, no internal resources to run the payroll, integration to a more sophisticated HR system and integration to $401 \mathrm{~K}$ or other retirement program and you choose only to do this thing that are in your core competencies [3].

Internal controls and monitoring are needed if your company outsources payroll to a third party, especially to ensure that payroll taxes are paid on timely basis and in full, so you can void penalties and double payments. You should also make sure the thirdparty is solvent, since there are few protection or option an available if the third-party processor files for bankruptcy after failing to pay your taxes or misusing your payroll tax funds [4].

And if your organization outsources payroll, you still need someone on staff who understands pay roll tax issues to monitor the third-party's operations. Your company remain liable for the taxes until they are paid, regardless of who makes the payment [4].

In their contracts with third-party vendors, some employers require that the payroll tax fund be set aside in trust-fund accounts, giving these priority in a processor's bankruptcy proceedings. Other preventive measures you can take to screen processors and monitor payments and returns:

- Regularly monitor your tax accounts via the internet for federal and most state $\operatorname{tax}$

- Conduct a biannual review of tax transcript

- If your firm has publicly traded stock, you may be required to seek a Statement on Auditing Standards (SAS) No 70 examination or obtain an SAS report to show that the third-party providers have met certain standards

- Make sure owners or officers or their designee independently review and authorized cash transfers to processor.

\section{Research Method}

The article use analyzing some literatures, and extracting information inside literature content, and also find meaning from dictionary help us to get the meaning of cloud payroll system and principles of internal control. 


\section{Result and Discussion}

Businesses have many options for processing payroll, start from in-house processing, using internal or vendor-supplied software, to outsourcing some or all function to an independent payroll provider [16]. Payroll three-party that called cloud payroll system is a special form of outsourcing system involving three companies, namely PT CR, Claud Payroll Manager and KAP ADC. The profile of each party is as follows:

- PT CR, is a Germany-based company engaged in telecommunication and has branch companies in several countries and one of them is in Indonesia. However, PT CR does not have a Finance Department and Human Resource Development Department (HRD). For improving the effectiveness of business processes, PT CR submit payroll system to $\mathrm{CP}$, so they can focus to develop their core business.

- CP Company is a cloud-based platform company in the world that provides payroll and payment services worldwide. Through a secure cloud-based platform, there are also 30 currencies, and 26 languages. Its works with payrolls partners in other countries to make payroll calculations. $C P$ has 7 services that are CP Payroll, CP Payment, CP Control, CP Connect, CP Collaborate, CP Local Payroll Information (LPI), and CP Insight.

- KAP ADC is a public accounting firm located in Jakarta, which specializes in audit assurance, but some clients also request non-audit services. The non-audit services such as accounting records, salary calculations, tax calculations, etc. KAP $A D C$ opens a wage calculation service due to the large number of requests from a Permanent Establishment (BUT) company or from a foreign company with a subsidiary in Indonesia but does not have a Finance Department and a HRD Department. Payroll calculation services performed by KAP ADC are not a one-party calculation, that is, the salary calculation is performed by the Finance Department of the company, based on the data recorded by the HRD Department, but the salary counting of two parties or three parties. The two-party salary calculation is performed by KAP ADC as a salary counting party and a company as a client. Meanwhile, payroll of three parties is done by, that is client company as first party, intermediary (CP) as second party, and KAP ADC as third party.

As explained early, PT CR is a telecommunication company in Germany, which has subsidiaries in Indonesia. PT CR in Indonesia does not have a human resources division, PT CR headquarters provides the responsibility to $C P$ to solve the existing employee 
recruitment system in Indonesia. Since CP is located in Singapore and lacks understanding of Indonesian regulations, CP appoints KAP ADC to calculate salaries of employees of PT CR Indonesia. As general, the process of cloud-based payroll system can be showed by Figure 1.

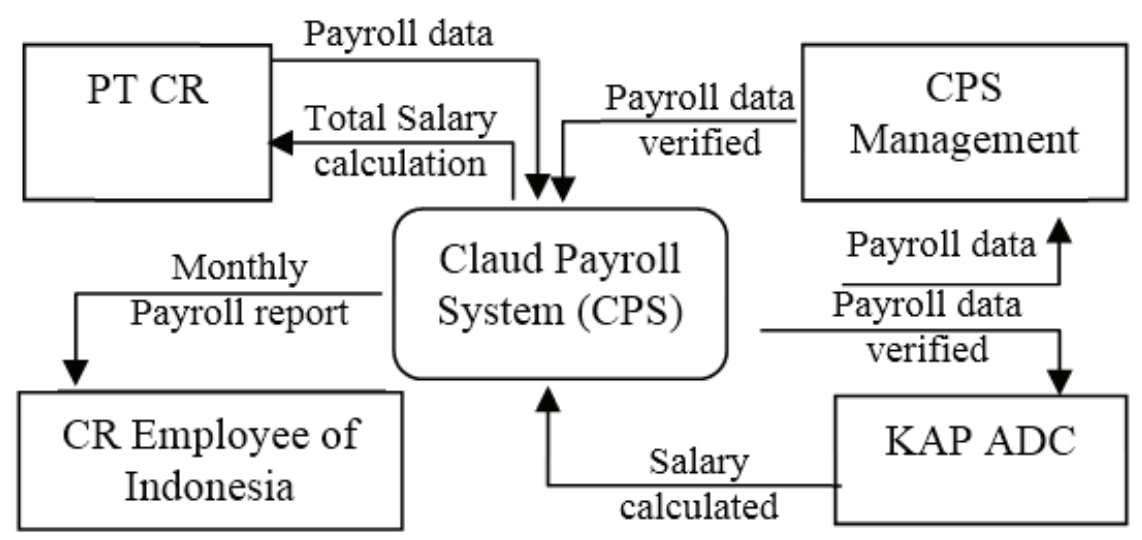

Figure 2: Process of Claud Base payroll system.

For more detail, the process can be explained as follows:

- The first, PT CR send payroll data of their employee in Indonesia to CP Company for calculation. CP company verify the data and send the verified data to KAP $A D C$. It is done because CP Company does not understand the payroll system applicable in Indonesia, such as family allowances, holidays, BPJS and others.

- After KAP ADC have received data that verified by CP company then KAP ADC calculated the salary that complying to Indonesia regulation payroll system and send it to CP Company.

- The CP company verify the document that sent by KAP ADC and send it to PT CR.

- If the document meets to PT CR requirement then PT CR will sign the document and return it to the CP company for the next process.

- CP company will transfer the salary and sent report to employee and PT CR.

According to the illustration of the aforementioned cloud payroll system, we can say that the payroll process has applied internal control principles. Segregation of duties have been applied in the payroll system and the authorization process is carried out correctly in accordance with its authority and responsibility. For example, data created by PT CR and the salary calculated by KAP ADC. It was verified by the CP company and 
authorized by PT CR before being executed by CP Company. Thus the manipulation of data will be difficult so that it can reduce the possibility of fraud.

\section{Conclusion}

According to result and discussion, we can say that:

1. Cloud-based payroll systems occur because of the development of communication and computer technology used in business processes.

2. Cloud-based payroll systems can reduce the probability of fraud because it has applied the principle of internal control.

\section{References}

[1] Anonymous, 2016. Industrie 4.0: Smart Manufacturing for the Future. German Trade and Invest

[2] Prama Arhando Julianto, 2016., Minister of Industry: National Industry Must Prepare to Face New Industrial Age, http://bisniskeuangan.kompas.com/read/2016/o9/ 23/231710626/menperin.industri.nasional.harus.bersiap.hadapi.era.industri.baru access on Septemebr 2oth 2016.

[3] ENSURING EFFECTIVE INTERNAL CONTROL OVER PAYROLL Avellanet, A Wayne Internal Auditing; Jul/Aug 2009; 24, 4; ProQuest pg. 23

[4] Is payroll outsourcing for you? Medlock, Jim AFP Exchange; Jul/Aug 2001; 21, 4; ProQuest pg. 44

[5] Randy Johnston, 2013, Payroll - To Be or Not To Be. https://www. CPAPracticeAdvisor.com/, access: Aug 10 ${ }^{\text {th }}, 2016$

[6] Anonymous, 2004., Pitfalls to Avoid If Your Company Outsources Payroll. HR Focus: Piyfalls to Avoid If Your Comapy Outsources Payroll; Nov 2004; 81, 11; ProQuest pg. 8

[7] Violita Saraswati, Darminto, Maria Goretti Wi Endang NP, 2014,. PAYROLL ACCOUNTING SYSTEM ANALYSIS AND WAGE IN EFFORTS TO SUPPORT ITS OBJECTIVES OF INTERNAL CONTROL (Studies in Batu Permai Hotel Batu), Jurnal Administrasi Bisnis (JAB)|Vol. 15 No. 2 Oktober 2014| 1 administrasibisnis.studentjurnal.ub.ac.id

[8] Richard Mou and Brian Kleiner, 2006. "Duty of care involving outsourced Payroll". Information Management \&Computer Security Vol. 14 No. 3, 2006 pp. 284-293.

[9] N Jazdi, 2014. Cyber Physical System in Context of Industry 4.0., IEEE 
[10] Wahlster, Wolfgang: "From Industry 1.0 to Industry 4.0: Towards the 4th Industrial Revolution," Forum Business meets Research. 2012.

[11] A. Mazak, and C. Huemer, "A Standards Framework for Value Networks in the Context of Industry 4.0" Proceedings of the IEEE IEEM, 2015

[12] Ronald Rosendahl, Nicole Schmidt, Arndt Lüder, and Daria Ryashentseva, "Industry 4.0 value networks in legacy systems", 2015 IEEE

[13] Keliang Zhou, Taigang Liu, and Lifeng Zhou, "Industry 4.0: Towards Future Industrial Opportunities and Challenges", 12th International Conference on Fuzzy Systems and Knowledge Discovery (FSKD), 2015

[14] Dr. Heiner Lasi, at.al., "Industry 4.0", Business Information System Engineering, $4 \mid 2014$

[15] Jack J. Champlain, "Auditing Information System", $2^{\text {nd }}$ Edition, John Wiley and Sons, 2003

[16] Jim Medlock, "Is payroll outsourcing for you?", AFP Exchange; Jul/Aug 2001; 21, 4; Proquest pg. 44 